た場合よりカブリ濃度が少なく，コントラストの上抟が みられた。また $90 \mathrm{kVp}$ を過きると急にコントラストが 低下すること方認められた。

\section{4. 胎表造影術について}

日本赤十字本部産院放射線部

（部長 三谷茂博士） 金沢章

昭和15年 “実践医理学”に発表された．日赤産院宇津 木・橋爪による報告以後。かならずしも無害と考学られ なくなったこと，われわれの技術および装置その他の進 歩により，失敗例がほとんど無くなったとと，それらの 結果新らしい知見壱得つつあるため，乙とに再びその方 法を報告したのである。

(1)使用造影剤 $40 \%$ モルョドール20cc。

(2)検 查対称 畸形その他異常胎児の疑. 正常の場合 放射線影響莡合せ考光応用す心゙きでな い.

(3)注入方法 腹壁在通し体温に加温した造影剂在羊 水採手後注入.

(4)撮影時期 注入後 10 20時間印随時.

(5)撮影方法 単純撮影で胎児を描写出来る程度.

単純撮影による子宮腔内胎韭の異常その他を正確に描 写し，辦断の確立を期することが出来たということ学報 告した。

\section{5. 本院における過去三カ年間の胎児 X線摆影数の頻 度について}

\section{新宿赤十字産院放射線科 坂井 良雄}

産婦人科単科と言う本産院の過去三力年間における $\mathrm{X}$ 線撮影頻度について検討して見ました．先ず外来患者総 数に対して腹部胎児と腧部, 間接撮影 Salpingographie などを二分して統計的に集計しました．先ず外来患者総 数 132,236 名に対して間接撮影者総数 6,317 名で $4.77 \%$ ， 胸部撮影が 601 件で $0.45 \%$ ，Salpingo が 265 件で0.20 \%合計 132,236 名に刘して 7,183 件で $5.43 \%$ となりま した。つぎに本院の主目的である子宮内胎児の撮影頻度 でありますが分婏総数 8,142 件に刘して Film に現われ た正常位が 449 件で全体の5.51\%，骨盤位が 273 件で $3.35 \%$ 横位が33件で $0.40 \%$ 双胎が54件で $0.66 \%$ 畸形が 4 件で $0.04 \% ， \mathrm{X}$ 線撮影患者総数は 813 件で分婏総数 8,142 件に刘する比率は $9.98 \%$ と言う結果になっており ます.X線撮影㭧者総数813件に刘して正常位が449件で $5.51 \%$ でありますが，骨盤位双胎畸形数が 364 件で 4.47

\%となっております，以上が本産院における過去三力年 間のX線撮影頻度でありますが，子宫内胎児の位置異常 が正常位の 5.51\% に対して $4.47 \%$ となっております。

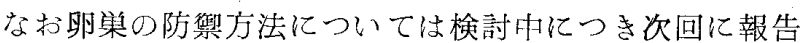
する．本院の場合異常分婏が割合に多いことがての結果 からも明らかのように考えられます。今回は数字ばかり 申上げましたが先ほぼも申上げましたように産婦人科を 主体としている本産院のような病院でのX線利用頻度に つきましてご報告申上げました。

\title{
66. X線撮影用「特殊フィルム・マーク」の研究
}

川崎市立小崎病院 片山通夫 新貝友三郎・河野 弘 富士重工 K.K. 大田病院

和多 慎・滝沢勝右

〔目的】X線写真の骖断にあたって, 撮影方法, 入射 角度おるび方向などが，フィルム上に表現されるならば， 読影上大いに参考になるであらうと考光，われわれは特 殊なフィルム・マーク在考案した。

[構造]

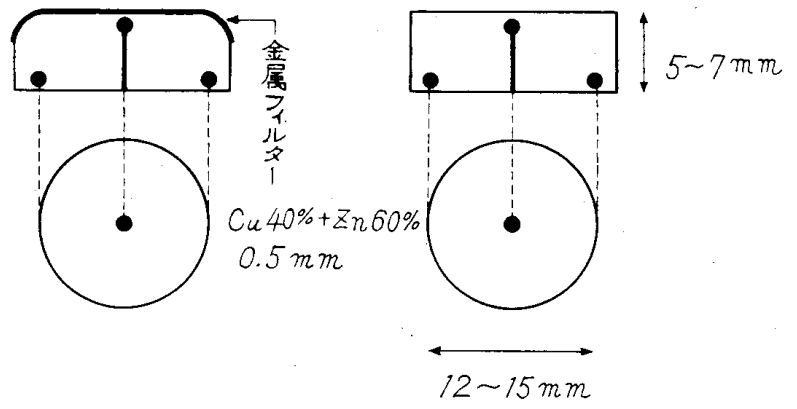

〔結果】（1）肺尖撮影，耳撮影などの入射角度を付け た撮影に有効であった。(2) 立体撮影では，左右の判別， 像の合致に有利であった。(3) 拡大撮影でも, 一見で判 別出来た。（4)廻転断首並びに普通円孤運動断層において 特に有効であり, 断首の種類, X線入射方向, 角度が判

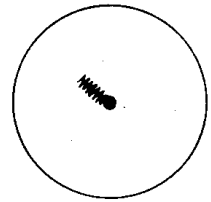

争度を付けた場合

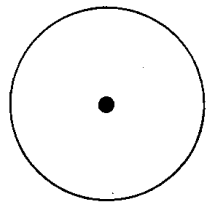

争度 ○の場合

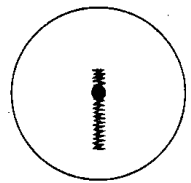

円张断層の争度 がズレている場合

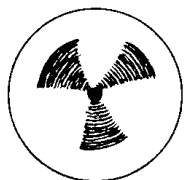

円軌道断曆 三呆曝写の場合

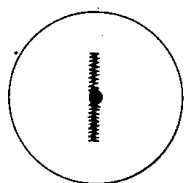

円弧断層の場合 